\title{
Bamboo Particles-Polyvinyl Chloride Composites: Analysis of Particles Size Distribution and Composites Performance
}

\author{
Shahril Anuar Bahari ${ }^{1} \&$ Andreas Krause ${ }^{2}$ \\ ${ }^{1}$ Department of Wood Biology and Wood Products, Faculty of Forest Sciences and Forest Ecology, \\ Georg-August-Universität Göttingen, Büsgenweg 4, 37077 Göttingen, Germany \\ ${ }^{2}$ Centre for Wood Science, Hamburg University, Leuschnerstraße 91, 21031 Hamburg, Germany \\ Correspondence: Shahril Anuar Bahari, Department of Wood Biology and Wood Products, Faculty of Forest \\ Sciences and Forest Ecology, Georg-August-Universität Göttingen, Büsgenweg 4, 37077 Göttingen, Germany. \\ E-mail: sbinbah@gwdg.de
}

Received: September 11, $2016 \quad$ Accepted: September 26, $2016 \quad$ Online Published: January 11, 2017

doi:10.5539/jmsr.v6n2p1 URL: http://dx.doi.org/10.5539/jmsr.v6n2p1

\begin{abstract}
Analysis of particles size distribution of Malaysian bamboo species (Bambusa vulgaris and Schizostachyum brachycladum) for polyvinyl chloride (PVC) composites production was conducted using dynamic image analysis (DIA). A wide distribution of bamboo particles length was recorded, varying from almost 0 to $1500-\mu \mathrm{m}$ for both species. Inadequate amount of actual particles length distribution from each sieve size (75- $\mu \mathrm{m}$ and $1-\mathrm{mm})$ was also recorded. DIA observed an increase of aspect ratio from small to large particles, and fine particles were recorded to be slightly elongated than the large ones. However, the effects of bamboo particles size on the finished PVC composites performance were uncertain, considerable of numerous other factors that influence the performance. Only impact and water uptake properties of composites have been obviously affected by different particles size. Greater modulus value is observed in composites with high particles loading, though low impact strength and water resistance were recorded. The incorporation of high concentration of selected processing lubricants in the composites formulation helped to improve the impact and water resistance of the composites. Malaysian bamboo particles-PVC composites performance between different species was equivalent, demonstrated that both species displayed identical behaviour for composites production.
\end{abstract}

Keywords: bamboo, particles size distribution, polymer composites

\section{Introduction}

Bamboo is a plant for multi uses, not only for traditional, but also for industrial applications. It is a member of subfamily Bambusoideae of family Graminae (grasses) (Tewari, 1993). Its maturation period is very short, about 3 to 5 years (Wahab, Samsi, Ariffin, \& Mustafa, 1997). Bamboo is a renewable resource due to its fast growing and wide availability especially in South East Asia, and it is also relatively cheaper than other wood resources (Gupta \& Kumar, 2008). Bamboo is globally classified into 70 genera with over 1500 species (Tewari, 1993). In South East Asia countries such as Malaysia, Wong (1995) documented bamboo into 59 species, where 25 species are introduced or only known in cultivation and 34 are indigenous and found wild. Its wide availability and good properties encouraged some wood-based industries to exploit bamboo for commercial markets: e.g. production of duroplastic composite boards, furniture, papers and textiles made out of bamboo (Gupta \& Kumar, 2008). The commercialization of bamboo-based products in Asia has tremendously increased the harvesting, manufacturing and marketing activities of bamboo (Hua \& Kobayashi, 2004), therefore, make it possible to utilize its particles for wood polymer composite (WPC) production. Carus and Eder (2014) predicted that the production and use of WPC in the construction and extrusion sectors in Europe will be increased from $190000 \mathrm{t}$ in 2012 to $400000 \mathrm{t}$ in 2020 . Therefore, it appears to be an opportunity in exploiting bamboo materials for WPC industry.

For this reason, introducing bamboo particles as a potential filler in WPC manufacturing will be also depending upon its particles behaviour. In principle, particles is commonly used as an extender/filler to reduce the polymer use, but sometimes it can also be used to modify the composite properties; e.g. increase strength and stiffness, scuff resistance, reduce tackiness, enhance electrical properties, and reduce material cost (Lutz \& Dunkelberger, 1992). In general, bamboo particles are classified as irregularly shaped particles which make the strength of the resultant composite will decrease with higher filler loading due to the inability of the filler to support stresses transferred 
from the polymer matrix (Kassim, 1999). In this context, bamboo particles filled-thermoplastic composite properties varied significantly with particles loading. Some correlations of the properties of this composite with filler loading have been previously reported. According to Kassim (1999), the increased of filler loading from 10 to $50 \%$, tensile modulus and flexural modulus were observed to increase by about $95.6 \%$ and $22.9 \%$ respectively, whereas tensile strength and flexural strength were decreased by 33.8 and $47.6 \%$ respectively. Based on a study by $\mathrm{Ke}$ and Jyh (2010), the highest bending strength was found in the bamboo particles-high density polyethylene (PE) composites with $20 \%$ or $30 \%$ bamboo particles with the maximum values of $23.7 \mathrm{MPa}$. As the flexural modulus of neat polypropylene (PP) was $1008 \mathrm{MPa}$, the PP composites mixed with $10 \%, 30 \%$, and $50 \%$ bamboo fibre increased by $87.8 \%, 215.3 \%$, and $383.2 \%$ respectively due to the stiffness increases of the composites (Lee, Chun, Doh, Kang, Lee, \& Paik, 2009). According to Samal, Mohanty, and Nayak (2009), tensile modulus of PP-bamboo/glass fibre hybrid composites increased steadily with the increase of filler content from $10 \%-40 \%$. The increase was attributed to the increased $\mathrm{wt} \%$ of the fibre loading within the matrix, leading to an efficient stress transfer from matrix to fiber (Samal et al., 2009). In term of impact strength, neat PP showed the values of $2.62 \mathrm{~kg} \mathrm{~cm} / \mathrm{cm}^{2}$, though the addition of $10 \%-50 \%$ bamboo fibre to the net PP, the values was ranged from $2.94-$ $3.13 \mathrm{~kg} \mathrm{~cm} / \mathrm{cm}^{2}$ (Lee et al., 2009). However, Ke and Jyh (2010) reported that bamboo particles-high density PE composites with $30 \%$ to $60 \%$ bamboo particles showed slight decreases in bending strength, and a drastic decrease when it was more than $60 \%$. According to Bouza, Lasagabaster, Abad, and Barral (2008), this was attributed by the aggregation of woody materials in the composition. Ge, Li, and Meng (2004) reported the reduction in strength behaviours was resulted from decreasing interfacial adhesion and homogeneity with increasing particles contents due to the presence of lignin and $\mathrm{OH}$ group in cellulose that influenced the agglomeration. With an increase of filler loading from $10 \%$ to $50 \%$, the water absorption of composites increased by $750 \%$, accountable to the increase in the filler surface area which was naturally hygroscopic (Kassim, 1999).

Apart from percentage of particles content in polymer composite, it is also understood that the effect of particles size on the properties of this type of composites was great (Kassim, 1999). Atuanya, Government, Okoye, and Onukwuli (2014) also confirmed the small effects of particles size on the strength performance of date palm wood-recycled low density PE composites. A reduction of the bamboo particles size used by Kassim (1999) from 0.25 to $0.12-\mathrm{mm}$ showed that most of the properties such as modulus of elasticity increased by $17.8 \%$, bending strength by $13.8 \%$, tensile strength by $9.74 \%$, and water absorption by $10.4 \%$. The increases could be due to the small particles covered a larger surface area within composites than the same weight of large particles (Kassim, 1999). However, Atuanya et al. (2014) reported only a small increase of tensile strength when the date palm wood particles size was increased. Using date palm wood particles at $30 \%$ loading rate, the ultimate tensile strength of composites with $150-\mu \mathrm{m}$ particles size was $9.48 \mathrm{MPa}, 212-\mu \mathrm{m}$ was $9.51 \mathrm{MPa}$, and $250-\mu \mathrm{m}$ was $9.56 \mathrm{MPa}$. In a different occasion, particles size also influenced the mixing performance of thermoplastic composite (Atuanya et al., 2014). Dispersion uniformity in the matrix becomes poorer when using high aspect ratio particles (Bledzki and Gassan, cited in Kim, Shim, Kim, Lee, Min, Jang, Abas, and Kim, 2015). Satov (2008) added that the fine particles will cause higher melt viscosities which generally influence the processing performance. In a different report by Stark and Gardner (2008), increasing the wood particles size increased the equilibrium moisture content of the composites. Nevertheless, it was specified that the materials with larger aspect ratio are the best candidate for composite's reinforcement (Gardner, Han, \& Wang, 2015). In accordance to Stark and Rowlands (2003), it was confirmed that increase in mechanical properties was found to correspond with increase in aspect ratio of particles. Filler with higher aspect ratio has improved the stiffness and stress transfer of composites (Kim et al., 2015). Although the aspect ratio of wood-based particles is only about $1-5$, the properties of composite made out of these particles are sufficient for many uses (Clemons, 2008). However, the effect of particles size on the properties of WPC is not sufficiently clear due to many factors such as thermoplastic type, wood content, particles geometry, coupling agent type, processing methods, and any other technical considerations.

Despite the favourable features of bamboo particles for WPC products, the application of this type of particles was mostly limited to PP and PE oriented products as stated in the literature. Only few works have been done on polyvinyl chloride (PVC)-based composites. Kim, Peck, Hwang, Hong, Hong, Huh, and Lee (2008) and Wang, Sheng, Chen, Mao, and Qian (2010) focused on the surface modification of China bamboo particles for PVC composites using chemical treatments. Another study by Sheng, Qian, and Wang (2014) concerned the influence of potassium permanganate pre-treatment of China bamboo particles on the properties of PVC composites. Consequently, the use of PVC in thermoplastic composites production should be further increased due to its excellent chemical resilience, long term stability, good weatherability, and strength (Kim and Pal, 2010).

In this study, Malaysian bamboo particles were utilized as filler in PVC composites production, with the specific objectives were to analyse the particles size distribution, and to determine the effect of particles size, particles 
loading, and processing lubricants concentration level on the basic performance of PVC composites. This study is essential in order to increase the utilization of bamboo particles in PVC/WPC industry and to increase the understanding of its fundamental performance.

\section{Experimental}

\subsection{Materials}

Two Malaysian bamboo species, Bambusa vulgaris and Schizostachyum brachycladum were selected in this study. The matured bamboos were harvested from a natural bamboo stand in Raub, Malaysia. The bamboo culms were chipped into smaller pieces, at about 10 to $30-\mathrm{mm}$ in length and 1 to $3-\mathrm{mm}$ in thickness, before being air-dried for several weeks. The dried chips were milled using a hammer mill to produce two groups of small particles using two sieve sizes: $75-\mu \mathrm{m}$ and $1-\mathrm{mm}$. These particles groups were selected in order to differentiate the effect of a very small and a very large particles size on the overall composite's performance. For composites production, PVC (Solvin, France) was used as a main matrix with other specific additives for PVC extrusion. The PVC's K-value was 63 , powder size range was 100 to $150-\mu \mathrm{m}$, while $\mathrm{T}_{\mathrm{g}}$ was $\pm 80^{\circ} \mathrm{C}$. The additives used were stabilizer Mark CZ2000 (Chemtura, Philadelphia, USA), processing aid Paraloid K120 (Dow Chemical Co., Michigan, USA), internal lubricant Loxiol G60 (Emery Oleochemicals, Cincinnati, USA), external lubricant Loxiol G21 (Emery Oleochemicals, Cincinnati, USA), external lubricant Ligalub GT (Peter Greven Fettchemie GmbH, Bad Münstereifel, Germany), and external lubricant Licocene PE4201 (Clariant, Muttenz, Switzerland).

\subsection{Analysis of Particles Size Distribution}

In order to obtain the information on bamboo particles size distribution, the analysis of particles shape and geometry was carried out using the dynamic image analysis (DIA) optical system with QICPIC (Sympatec) sensor machine (Figure 1). A small amount of dried particles from two different sieve size groups (75- $\mu \mathrm{m}$ and 1-mm) were collected and air-conditioned at $22^{\circ} \mathrm{C}$ and $65 \%$ humidity for one week. The range of measurement area in this system was between 5 to $5120-\mu \mathrm{m}$ (M6). The dispersion of the particles through the scanning optic was performed by a dry dispersion unit in DIA system with 1 bar air pressure. The particles were separated from each other by the transportation of air pressure from this dispersion unit. Typically, more than 1 million particles are needed for each measurement to reach the maximum error value below $1 \%$ (International Organization for Standardization ISO/DIS 14488, 2007). The particles were oriented randomly and captured with the highest possible contrast in order to detect the precise images. The bamboo particles geometry was analysed based on their size (length) distribution and shape (aspect ratio and elongation). The evaluation was also conducted with $\mathrm{x}_{10}, \mathrm{x}_{50}$ and $\mathrm{x}_{90}$ values of statistical interval (means of the $\mathrm{x}_{\mathrm{y}}$ value is that $\mathrm{y}$ percent of the particles are smaller (shorter) than $\mathrm{x}$ ) (Grüneberg, 2010). Some specific terms were used in the software analysis, such as length of fibre (LEFI) and diameter of fibre (DIFI). According to DIA system, LEFI is defined as the length of the shortest path between the two most distant end points of the fibres/particles, while DIFI as the projection area of the fibre/particle divided by the length of all fibres/particles sections.

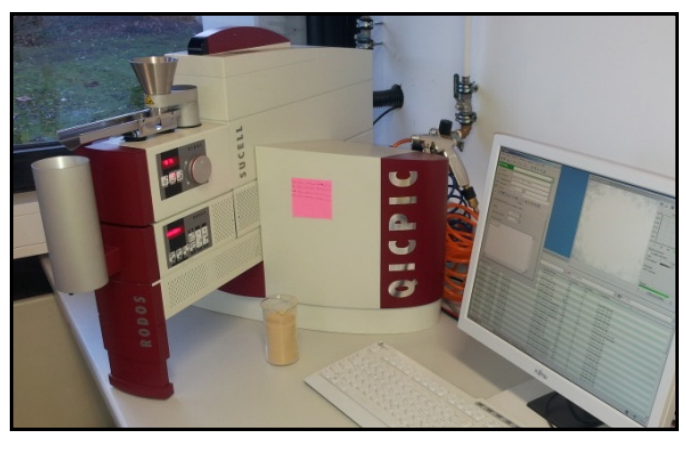

(a)

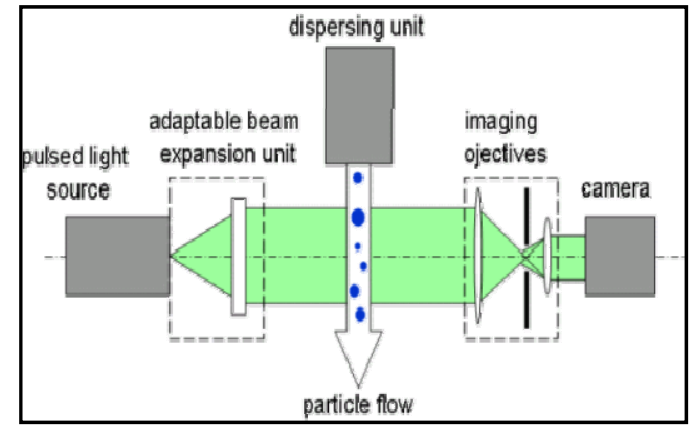

(b)

Figure 1. DIA system: (a) a combination of dynamic image analysis sensor QICPIC, powerful dispersers (dry disperser RODOS/L) and dry feeder, with image analysis software, (b) schematic diagram of optical set-up in combination with dispersion unit for image analysis process (Sympatec) 


\subsection{Composites Production}

The production process of bamboo particles-PVC composites was separated into the following steps. The particles from both size groups and both species were dried in a drying oven at $103^{\circ} \mathrm{C}$ for several days to reduce the moisture contents to $2 \%-3 \%$, before being blended together with PVC and other additives in powder form. The compositions of PVC, additives and bamboo particles in parts per hundred (pph) for dry blend process are shown in Table 1. The content and function of additives such as Mark CZ2000, Paraloid K120, Loxiol G60, Loxiol G21, Ligalub GT and Licocene PE4201 are also listed in the table. Two different blending compositions (based on different processing lubricants concentration levels) were used: 1.2 and 3.6 pph for Loxiol G60 (dicarboxylic acid ester/internal lubricant), and, 0.15 and $0.45 \mathrm{pph}$ for Licocene PE4201 (polyethylene wax/external lubricant). Composition $1\left(\mathrm{C}_{1}\right)$ indicated the ingredients with low concentration of these lubricants, while composition $2\left(\mathrm{C}_{2}\right)$ indicated high concentration. The different compositions of lubricants were considered in order to determine the influence of the usage of these lubricants on the overall composites' performance. In point of fact, an independent study on fusion behaviour of bamboo particles-PVC dry blend was conducted, which reported the compounding torque and temperature of dry blending process with different concentration of additives. Excellent mixing stability (low compounding torque and homogeneous temperature) was observed when the concentrations of Loxiol G60 and Licocene PE4201 were increased three times, reason of an increased lubricants concentration.

The bamboo particles, PVC, and additives were mixed together to dry blend powder in a hot-cool mixer (Reimelt Henschel, FM L $30 \mathrm{KM} \mathrm{85)} \mathrm{until} \mathrm{the} \mathrm{blending} \mathrm{temperature} \mathrm{of} 120^{\circ} \mathrm{C}$ (for hot section) and $40^{\circ} \mathrm{C}$ (for cool section) were reached. Bamboo particles were mixed at different percentage ratio: $25 \%$ and $50 \% \mathrm{w} / \mathrm{w}$. These ratios were considered due to the intention in determining the influence of a very low and a very high content of bamboo particles on the composites performance. In this study, the maximum percentage of bamboo particles was $50 \%$, attributable to high viscosity of the PVC (Müller, 2012) and numerous additives used in the blending process (Jiang and Kamdem, cited in Müller, 2012).

All dry-blend powders were compounded by counter-rotating screw extrusion (Leistritz MICRO 27 40D) to produce granules. The average compounding temperature in the extruder zone was $180^{\circ} \mathrm{C}$ with a screw rotation of $90 \mathrm{rpm}$. The granules were finally consolidated into compression molded boards using a temperated hydraulic press. The temperature, pressure and duration of hot press was $190^{\circ} \mathrm{C}, 60$ bar and 5 minutes, respectively. Pure $\mathrm{PVC}$ (without bamboo particles) using $\mathrm{C}_{1}$ were also processed under the same conditions for comparison purposes.

Table 1. Compositions of PVC, additives, and bamboo particles for dry-blend process

\begin{tabular}{lcccc}
\hline \multicolumn{1}{c}{ Raw materials } & Contents & Functions & \multicolumn{2}{c}{ Parts per hundred (pph) } \\
\cline { 3 - 5 } & & Matrix & $\mathrm{C}_{1}$ & $\mathrm{C}_{2}$ \\
\hline PVC $($ K value $=63)$ & Calcium/zinc & Stabilizer & 100 & 100 \\
Mark CZ2000 & Acrylic acid & Processing aid & 2.5 & 2.5 \\
Paraloid K120 & Dicarboxylic acid ester & Internal lubricant & 1.0 & 1.0 \\
Loxiol G60 & Fatty acid & External lubricant & 0.2 & 3.6 \\
Loxiol G21 & Glycerol ester & External lubricant & 1.2 & 0.2 \\
Ligalub GT & Polyethylene wax & External lubricant & 0.15 & 0.45 \\
Licocene PE4201 & Filler & 106.25 & 108.95 \\
\hline Bamboo particles & & &
\end{tabular}

\subsection{Performance Test of Composites}

Performance of all composites were measured in a 3-point static bending, tensile, impact and water resistance tests. Samples for all tests were cut and conditioned at $22^{\circ} \mathrm{C}$ and $65 \%$ relative humidity for about one week prior to testing. Bending and tensile tests were conducted using a universal testing machine model Zwick/Roell (Z010 Allround Line) equipped with Test Expert II software, fitted with $10 \mathrm{kN}$ load cell according to Deutsches Institut für Normung DIN EN ISO 178 (2003) and Deutsches Institut für Normung DIN EN ISO 527-1 (1993), respectively. The dimension of bending samples was $80 \times 10 \times 4 \mathrm{~mm}$ (length $\times$ width $\times$ thickness, respectively). The load was applied at a speed of $1 \mathrm{~mm} / \mathrm{min}$ until failure occurred. Thickness and width of tensile samples at necked-down section was 4 and $10 \mathrm{~mm}$ respectively, while samples' length was $190 \mathrm{~mm}$. The samples were held in small grips while testing, at a crosshead speed of $1 \mathrm{~mm} / \mathrm{min}$ until fracture. The consequent bending modulus, bending strength, tensile modulus and tensile strength were determined in these tests. Samples with the dimension 
similar to bending were also prepared for impact and water uptake tests. Impact test was conducted according to Deutsches Institut für Normung DIN EN ISO 179 - 1 (2006) in an un-notched state. The test was performed in a Charpy impact machine with 1 Joule (J) hammer and $60 \mathrm{~mm}$ support span. Samples for water resistance test were oven-dried at $103^{\circ} \mathrm{C}$ to remove moisture prior to the immersion in distilled water at room temperature, according to International Organization for Standardization ISO 62 (2008). The samples were periodically taken out of water in between 1600 hours. The sample's surfaces were wiped before the measurement and weighed for water uptake determination using Equation 1:

$$
\text { Weight changes }=\left(\mathrm{W}_{\text {submersed }}-\mathrm{W}_{1} / \mathrm{W}_{1}\right) \times 100(\%) \quad \ldots \text { Equation } 1
$$

where:

$\mathrm{W}_{1}$ is weight of dried sample (g), and

$\mathrm{W}_{\text {submersed }}$ is change in weight $(\mathrm{g})$.

\section{Results and Discussion}

\subsection{Particles Size Distribution}

Figure 2 shows the cumulative distribution of particles length from different sieve size ( $75-\mu \mathrm{m}$ and $1-\mathrm{mm})$. Table 2 presents the particles length at $\mathrm{x}_{10}, \mathrm{x}_{50}$ and $\mathrm{x}_{90}$ of statistical interval, while Table 3 displays the cumulative distribution and aspect ratio of particles. The elongation of particles is depicted in Figure 3.

A total number of 9.3 to 24.8 million particles were measured and analysed by DIA for each sieve size group (Table 2). Based on Figure 2, a wide distribution of particles length was recorded, varying from almost 0 to $1500-\mu \mathrm{m}$. As an example, analysis of $75-\mu \mathrm{m}$ size group showed that $95 \%$ of $B$. vulgaris and $96 \%$ of $S$. brachycladum particles length were less than $250-\mu \mathrm{m}$, whereas for $1 \mathrm{~mm}, 80 \%$ and $70 \%$ of the respective $B$. vulgaris and S. brachycladum particles length were less than $250-\mu \mathrm{m}$ (Figure 2). This implied that a wide range of particles size was recorded for each particles size group, suggested the insufficient amount of actual particles length distribution for each sieve size.

According to Table 2, the evaluation on $\mathrm{x}_{10}, \mathrm{x}_{50}$ and $\mathrm{x}_{90}$ of statistical intervals confirmed the variation of particles length. $\mathrm{X}_{10}$ showed that both sieve size groups had a similar amount of fine particles (between 12.9 to $16.0-\mu \mathrm{m}$ ), whereas $\mathrm{X}_{50}$ recorded a wider distribution of particles (between 57.9 to 100.6- $\mu \mathrm{m}$ ). Meanwhile, $\mathrm{x}_{90}$ showed the highest variation of particles length between different sieve size groups for both species, which ranged from 178.9 to $722.2-\mu \mathrm{m}$.

Based on Table 3, both bamboo species showed an increment of aspect ratio from small to large particles for both sieve size groups. A higher aspect ratio was recorded from the longest particles. For all groups, only $5.9 \%$ to $7.5 \%$ of particles had an aspect ratio of less than 1.7. About $99 \%$ of particles from $B$. vulgaris/75- $\mu$ m group had an aspect ratio of less than 4.2. According to Gardner et al. (2015), the large-sized particles with high aspect ratio provided better mechanical properties than the small-sized particles. Transfer efficiency of load from matrix to wood fiber could be possibly increased with increasing fiber length/diameter ratio (Migneault, Koubaa, Erchiqui, Chaala, Englund, Krause, \& Wolcott, 2008). Based on the small increase of aspect ratio in this study, reinforcement and properties of bamboo particles-PVC composite are possibly improved, although the reinforcing potential for this type of composite seems to be quite limited.

Based on the elongation analysis depicted in Figure 3, particles from $75-\mu \mathrm{m}$ size group for both species were a little more elongated than $1-\mathrm{mm}$. However, its effect on the actual composite properties was not definitely ascertainable, as the amount of actual particles length in each sieve size group was inadequate. Many other factors influencing the composite properties (e.g. processing conditions and other raw material attributes such as particles loading and processing lubricants concentration) have to be considered. This phenomenon is explained through composite's performance results in the following discussion. 


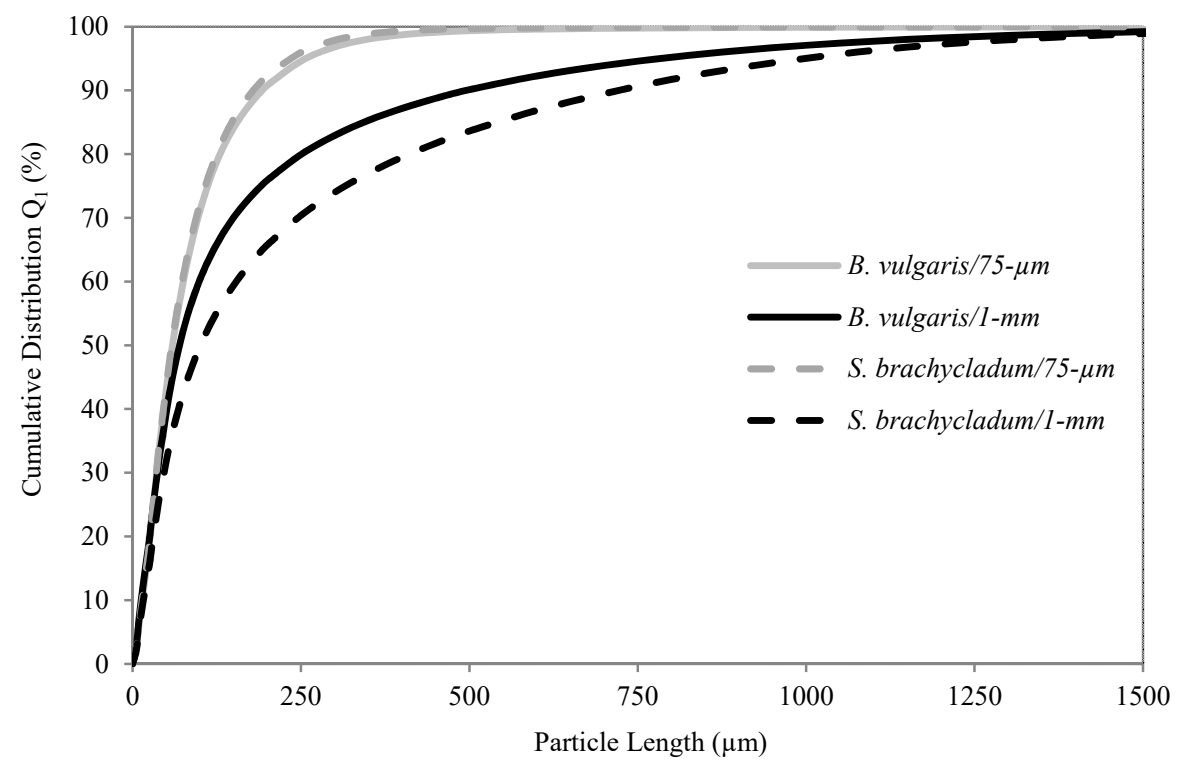

Figure 2. Particle length cumulative distribution of Malaysian bamboo species from different sieve size $(75-\mu \mathrm{m}$ and 1-mm) measured from DIA optical system

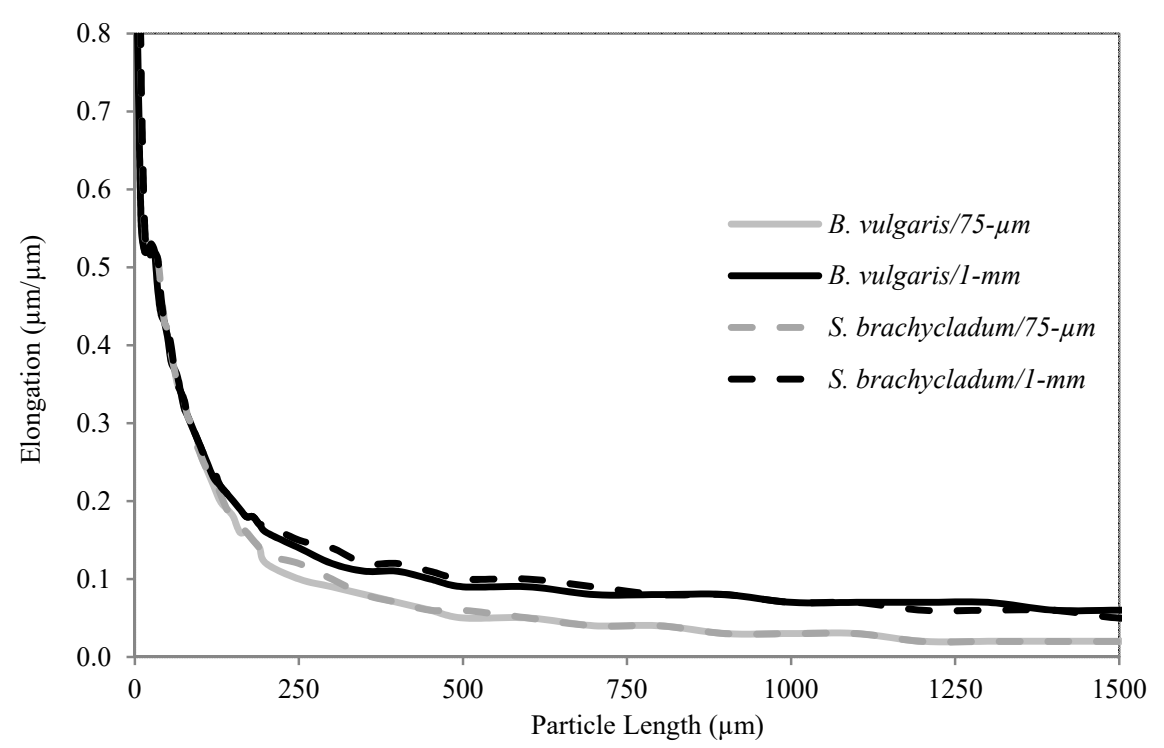

Figure 3. Particle elongation of Malaysian bamboo species from different sieve size (75- $\mu \mathrm{m}$ and 1-mm) measured from DIA optical system

Table 2. Evaluation on particle length of Malaysian bamboo species from different sieve size at $\mathrm{x}_{10^{-}}, \mathrm{x}_{50^{-}}$and $\mathrm{x}_{90}$-value of statistical intervals

\begin{tabular}{cccccc}
\hline \multirow{2}{*}{ Species } & Sieve size & $\begin{array}{c}\text { No. of analysed particles } \\
\text { (Million) }\end{array}$ & $\mathrm{x}_{10}$-value $(\mu \mathrm{m})$ & $\mathrm{x}_{50}$-value $(\mu \mathrm{m})$ & $\mathrm{x}_{90}$-value $(\mu \mathrm{m})$ \\
\hline \multirow{2}{*}{$\mathrm{Bv}$} & $75-\mu \mathrm{m}$ & 24.1 & 14.1 & 59.2 & 192.5 \\
& $1-\mathrm{mm}$ & 13.3 & 12.9 & 69.8 & 495.8 \\
\hline \multirow{2}{*}{$\mathrm{Sb}$} & $75-\mu \mathrm{m}$ & 24.8 & 14.2 & 57.9 & 178.9 \\
& $1-\mathrm{mm}$ & 9.3 & 16.0 & 100.6 & 722.2 \\
\hline
\end{tabular}

Note: $\mathrm{Bv}=$ B. vulgaris, $\mathrm{Sb}=$ S. brachycladum 
Table 3. Cumulative distribution and aspect ratio of Malaysian bamboo particles

\begin{tabular}{|c|c|c|c|c|}
\hline Species & $\begin{array}{l}\text { Sieve } \\
\text { size }\end{array}$ & $\begin{array}{c}\text { Length } \\
(\mu \mathrm{m})\end{array}$ & $\begin{array}{c}\text { Cumulative } \\
\text { distribution (\%) }\end{array}$ & $\begin{array}{c}\text { Aspect } \\
\text { ratio } \\
\end{array}$ \\
\hline \multirow{6}{*}{$\mathrm{Bv}$} & \multirow{3}{*}{$75-\mu \mathrm{m}$} & 10 & 6.7 & 1.7 \\
\hline & & 100 & 71.1 & 2.1 \\
\hline & & 500 & 99.4 & 4.2 \\
\hline & \multirow{3}{*}{$1-\mathrm{mm}$} & 10 & 7.5 & 1.7 \\
\hline & & 100 & 60.3 & 2.1 \\
\hline & & 500 & 90.1 & 4.0 \\
\hline \multirow{6}{*}{$\mathrm{Sb}$} & \multirow{3}{*}{$75-\mu \mathrm{m}$} & 10 & 6.6 & 1.7 \\
\hline & & 100 & 72.2 & 2.1 \\
\hline & & 500 & 99.7 & 3.3 \\
\hline & \multirow{3}{*}{$1-\mathrm{mm}$} & 10 & 5.9 & 1.7 \\
\hline & & 100 & 49.9 & 2.2 \\
\hline & & 500 & 83.6 & 3.4 \\
\hline
\end{tabular}

Note: $\mathrm{Bv}=$ B. Vulgaris, $\mathrm{Sb}=$ S. brachycladum

\subsection{Composites Performance}

\subsubsection{Bending and Tensile Properties}

Based on the observation, B. vulgaris and S. brachycladum were comparable in term of composites performance; established an understanding that both species behaved identically. Shown in Figures 4 and 5 are the bending properties of the composites with different particles size, particles loading, and processing lubricants concentration for B. vulgaris and S. brachycladum, respectively, whereas the tensile properties are shown in Figures 6 and 7 for the respective bamboo species. Impact property of the composites for both species is depicted in Figure 8. Water uptake property of the composites is displayed in Figures 9 and 10 for B. vulgaris and S. brachycladum, respectively.

According to Figures 4 (a) and 5 (a), Malaysian bamboo particles size had a very small effect on bending modulus properties of PVC composites, in which, a slight increase of bending modulus was recorded for composites with 1-mm particles size in comparison to $75-\mu \mathrm{m}$. The improvement of bending modulus of composites with large particles can be related to the increased aspect ratio of the longest particles as listed in Table 3 that influenced the better bending modulus. Particles or fibres with a higher aspect ratio may improve the stress transfer between matrix and particles/fibres and finally tend to strengthen the bending modulus properties of the composites (Gozdecki, Zajchowski, Kociszewski, Wilczyñski, \& Mirowski, 2011). However, this trend is observed only for composites from $\mathrm{C}_{1}$ formulation. Based on Figure 6 (a), in contrast, the B. vulgaris particles-PVC composites from $\mathrm{C}_{1}$ showed slightly lower tensile modulus value when using 1-mm particles size. On the other hand, it was observed that the influence of particles size on bending modulus and tensile modulus of composites from $\mathrm{C}_{2}$ formulation was uncertain (Figure 4 (a), 5 (a), 6 (a), and 7 (a)). In this condition, the variation of bending modulus and tensile modulus of composites from $\mathrm{C}_{2}$ formulation does not depend on the different of particles sizes.

Furthermore, the incorporation of Malaysian bamboo particles has greatly improved the bending modulus and tensile modulus of PVC composites. According to Figures 4 (a), 5 (a), 6 (a), and 7 (a), composites with 50\% bamboo particles loading had bending modulus of up to $34 \%$ higher and tensile modulus of up to $32 \%$ higher compared to composites with $25 \%$ bamboo particles loading. In relation to the pure PVC composites in Table 4 , it was recorded that the bending modulus and tensile modulus of Malaysian bamboo particles-PVC composites were up to $81 \%$ higher and $59 \%$ higher for the respective bending modulus and tensile modulus as compared to pure PVC composites. The high bending modulus and tensile modulus of Malaysian bamboo particles-PVC composites in this study were influenced by the high ratio of particles that increased the stiffness of the composites. Based on the records, $S$. brachycladum particles-PVC composites with $1-\mathrm{mm}$ particles size $/ 50 \%$ particles loading $/ \mathrm{C}_{1}$ showed the highest bending modulus $\left(5203 \mathrm{~N} / \mathrm{mm}^{2}\right)$, meanwhile B. vulgaris particles-PVC composites with $75-\mu \mathrm{m}$ particles size $/ 50 \%$ particles loading $/ \mathrm{C}_{2}$ showed the highest tensile modulus $\left(5380 \mathrm{~N} / \mathrm{mm}^{2}\right)$ among others.

However, based on Table 4, Figures 4 (b), 5 (b), 6 (b), and 7 (b), the bending strength and tensile strength of composites with presence of bamboo particles and high particles loading were generally lower. The high ratio of bamboo particles in the composites did not help in supporting maximum bending rupture and maximum tensile rupture. Kassim, Rahman, and Ramlan (2007) in their study reported that reduced modulus of rupture of natural 
particles-filled thermoplastic composites was a consequence of decreased deformability of rigid interphase between particles and matrix. It is previously reported that micro voids were typically formed in thermoplastic composites based on natural filler, due to interfacial failure between natural fillers and matrix, which finally influenced the low tensile strength in general (Chen, Mao, Xue, Deng, \& Lin, 2013). According to the current study, the maximum value of bending strength was recorded by $B$. vulgaris particles-PVC composites with 1-mm particles size $/ 25 \%$ particles loading $/ \mathrm{C}_{1}\left(60 \mathrm{~N} / \mathrm{mm}^{2}\right)$, whereas, $S$. brachycladum particles-PVC composites with $75-\mu \mathrm{m}$ particles size $/ 25 \%$ particles loading $/ \mathrm{C}_{1}$ showed the highest tensile strength value $\left(31 \mathrm{~N} / \mathrm{mm}^{2}\right)$.

Based on Figures 4 and 5, there were no significant effects of processing lubricants concentration level on bending and tensile properties of composites in this study. In this case, modifying the processing lubricants concentration has no impact on the bending and tensile properties of the Malaysian bamboo particles-PVC composites.

Overall results showed that the bending and tensile properties of Malaysian bamboo particles-PVC composites were superior when compared to the other study on bamboo-based thermoplastic composites. Chen, Guo, and Mi (1998) reported the values of tensile strength of bamboo fibre-PP composites (at $20 \%-60 \%$ bamboo loading) were less than $20 \mathrm{MPa}$, tensile modulus values were less than $4000 \mathrm{MPa}$, whereas Mohanty and Nayak (2010) revealed the value of bending modulus and bending strength of untreated bamboo-high density PE composites (at $40 \%$ bamboo loading) were $2987.70 \mathrm{MPa}$ and $25.35 \mathrm{MPa}$, respectively.

Table 4. Properties of pure PVC (without bamboo particles) composites using $\mathrm{C}_{1}$

\begin{tabular}{lc}
\hline \multicolumn{1}{c}{ Properties } & Mean values \\
\hline Bending modulus $\left(\mathrm{N} / \mathrm{mm}^{2}\right)$ & $2866(44.2)$ \\
Bending strength $\left(\mathrm{N} / \mathrm{mm}^{2}\right)$ & $73(2.7)$ \\
Tensile modulus $\left(\mathrm{N} / \mathrm{mm}^{2}\right)$ & $3295(546.1)$ \\
Tensile strength $\left(\mathrm{N} / \mathrm{mm}^{2}\right)$ & $52(7.5)$ \\
Impact $\left(\mathrm{kJ} / \mathrm{m}^{2}\right)$ & $23(0.9)$ \\
\hline
\end{tabular}

Note: Standard deviations in parentheses

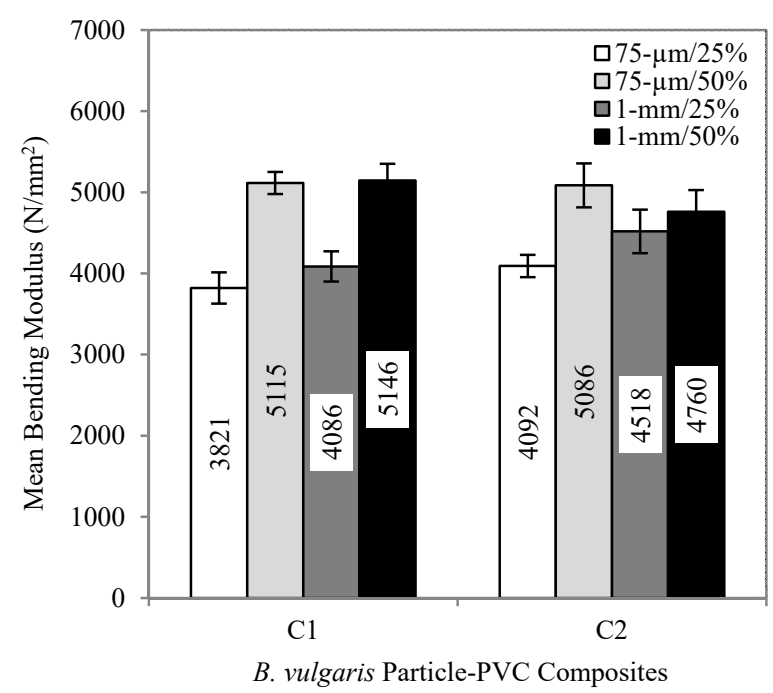

(a)

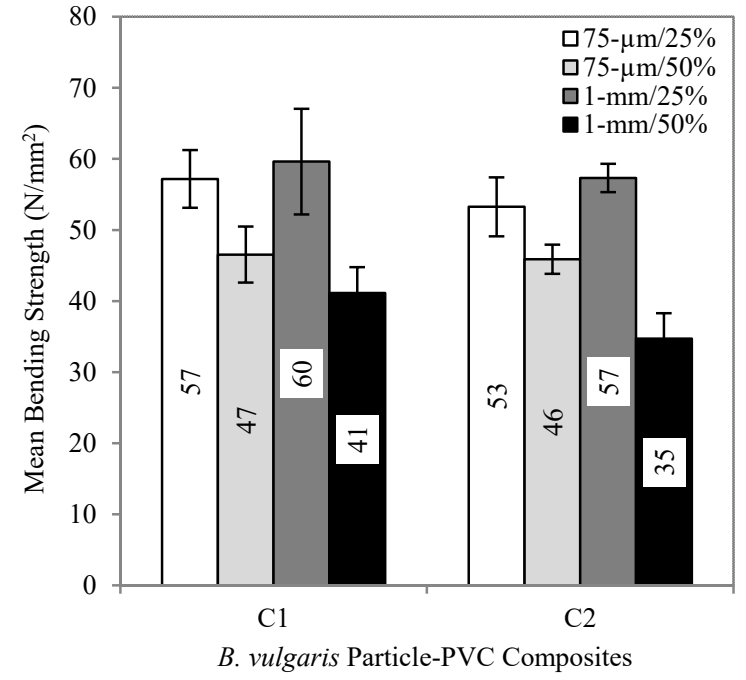

(b)

Figure 4. Bending property of B. vulgaris particles-PVC composites with different particles sieve size, particles mixing ratio and processing lubricants content level; (a) mean bending modulus, (b) mean bending strength 


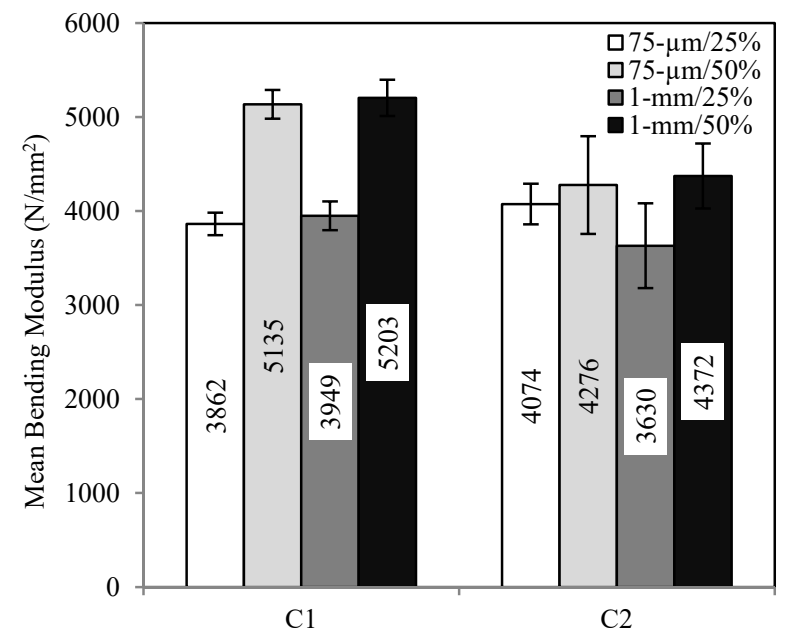

S. brachycladum Particle-PVC Composites

(a)

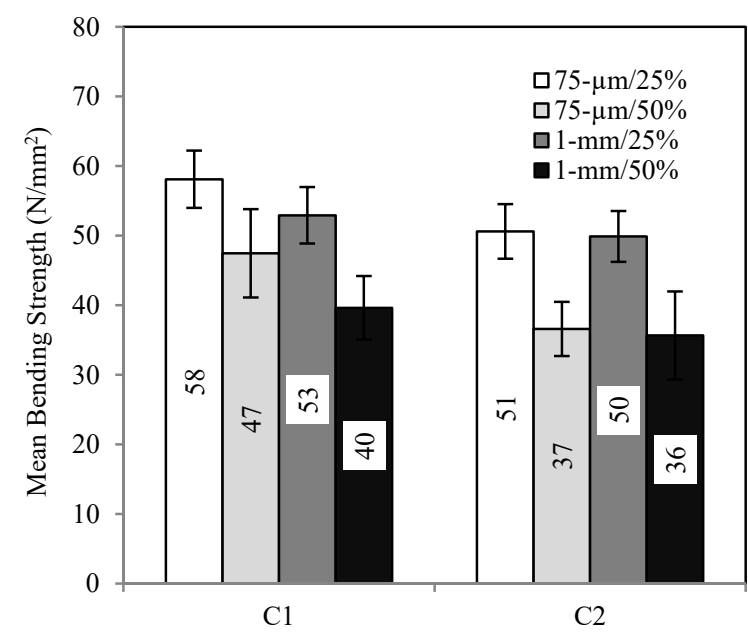

S. brachycladum Particle-PVC Composites

(b)

Figure 5. Bending property of S. brachycladum particles-PVC composites with different particles sieve size, particles mixing ratio, and processing lubricants content level; (a) mean bending modulus, (b) mean bending strength

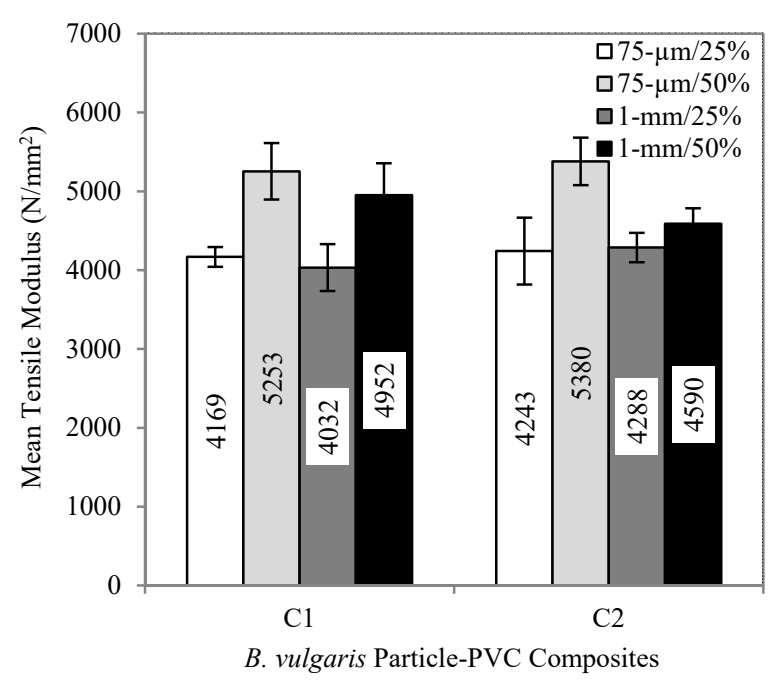

(a)

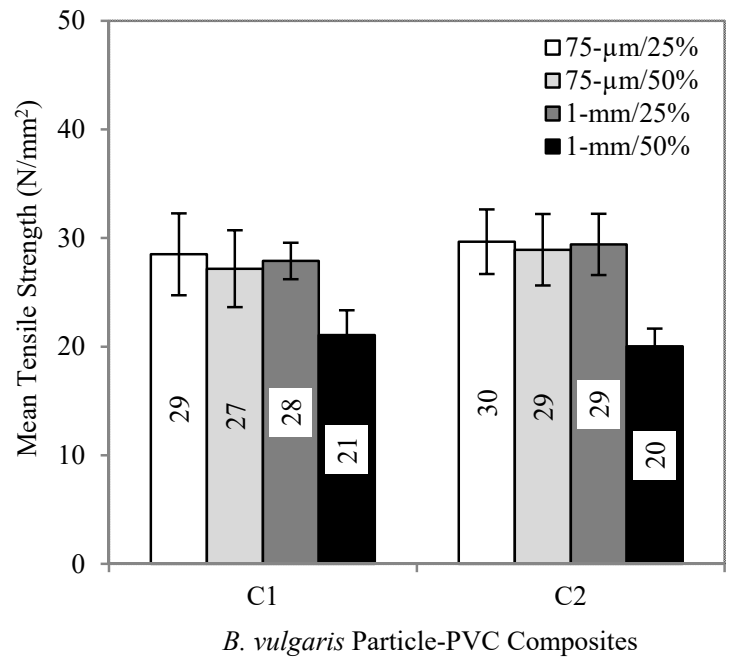

(b)

Figure 6. Tensile property of B. vulgaris particles-PVC composites with different particles sieve size, particles mixing ratio, and processing lubricants content level; (a) mean tensile modulus, (b) mean tensile strength 


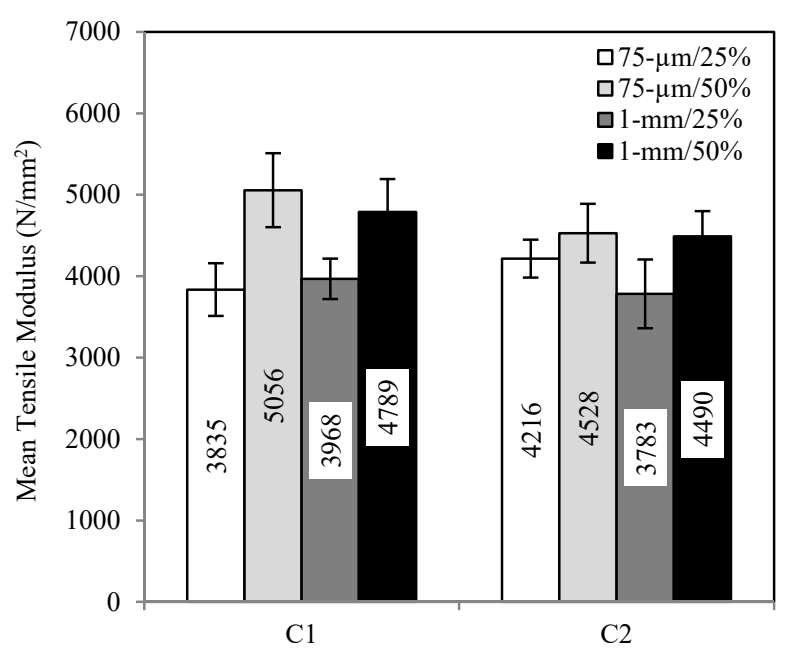

S. brachycladum Particle-PVC Composites

(a)

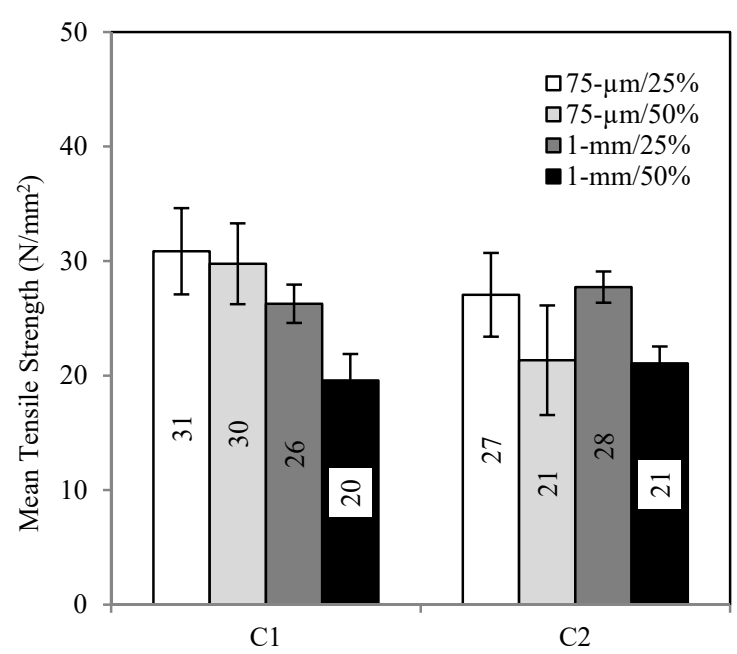

S. brachycladum Particle-PVC Composites

(b)

Figure 7. Tensile property of $S$. brachycladum particles-PVC composites with different particles sieve size, particles mixing ratio, and processing lubricants content level; (a) mean tensile modulus, (b) mean tensile strength

\subsubsection{Impact Properties}

According to Figure 8, the use of fine bamboo particles $(75-\mu \mathrm{m})$ in the formulation was capable in influencing the increases of impact strength of the composites. This was probably due to the binding competency of particles with the matrix due to fine size. Fine natural fibres entangle less, have more resistance to breaking, and have a high surface area that make their distribution into the polymer matrix is more homogeneous (Zazyczny \& Matuana, 2005), therefore, help to improve the impact resistance of the composites.

For particles loading aspect, the impact strength of composites with $25 \%$ bamboo particles was from 77 to $1150 \%$ greater than composites with $50 \%$ bamboo particles. However, in a general comparison to pure PVC composites in Table 4, the impact strength of bamboo particles-filled PVC composites is diminished by the presence of bamboo. The presence of bamboo particles in the formulation has possibly influenced the defieciency in supporting the sudden impact loads.

Furthermore, composites with high concentration of processing lubricants $\left(\mathrm{C}_{2}\right)$ exhibited higher impact strength compared to low concentration $\left(\mathrm{C}_{1}\right)$. The incorporation of high amount of these internal and external processing lubricants helped to improve the impact strength of the composites in this study. As the internal lubricant promote the fusion process and reduce the melt viscosity of PVC-filler mixing, the external lubricant tends to migrate to the surface of PVC composites mixture to reduce the friction between PVC melt and processing machine surfaces (Thacker, 2008), thus simultaneously help to improve the resistance toward impact load. According to Figure 8, the maximun mean impact strength value that the composite from $\mathrm{C}_{2}$ can achieve was $4.9 \mathrm{~kJ} / \mathrm{m}^{2}$ (recorded from $S$. brachycladum $/ 1-\mathrm{mm}$ particles sieve size $/ 25 \%$ particles mixing ratio).

While excellent bending modulus and tensile modulus have been recorded, impact result shows that the average impact strength of Malaysian bamboo particles-PVC composites are considered inferior in the context of high-rated sudden load applications. Under the best of circumstances, a balance of stiffness and impact resistance is desired for any kind of composites products to be used in load-bearing application (Robinson, Ferrigno, \& Grossman, 2008). Due to the outstanding modulus of the composites regardless of particles size and particles loading, the formulation of $75-\mu \mathrm{m}$ particles size $/ 25 \%$ particles loading $/ \mathrm{C}_{2}$ for $B$. vulgaris, and $1-\mathrm{mm}$ particles size $/ 25 \%$ particles loading $/ \mathrm{C}_{2}$ for $S$. brachycladum may be used in order to achieve the optimum impact resistance stipulated in Figure 8. 


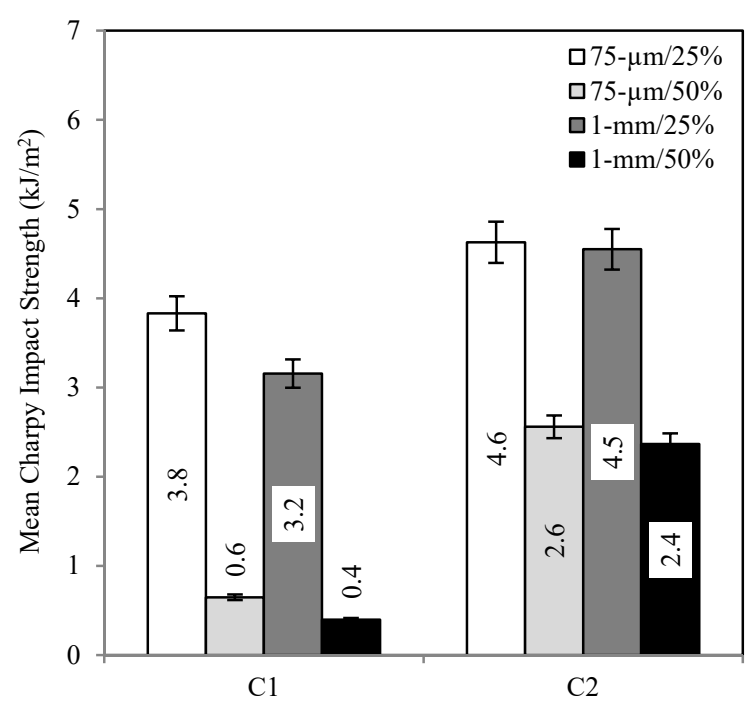

B. vulgaris Particle-PVC Composites

(a)

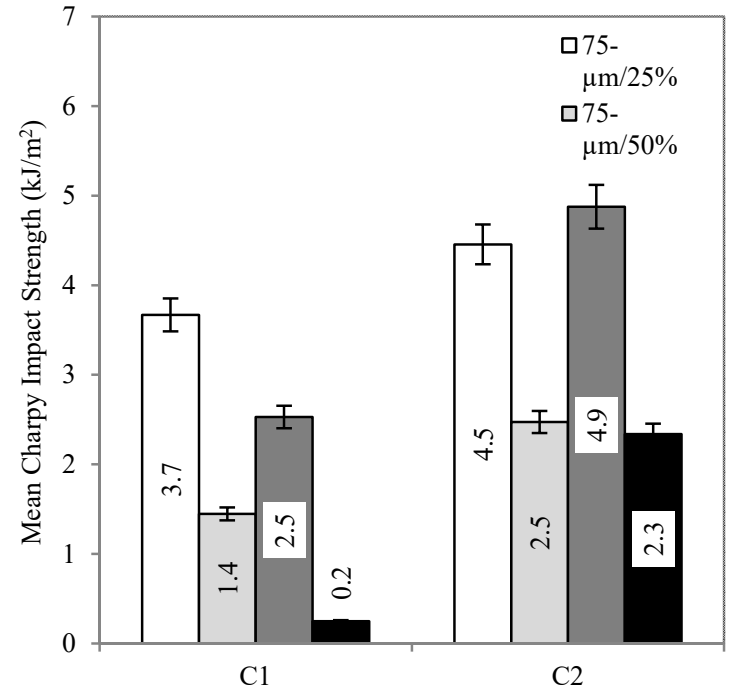

S. brachycladum Particle-PVC Composites

(b)

Figure 8. Impact of Malaysian bamboo particles-PVC composites with different particles size, particles mixing ratio, and processing lubricants content level: (a) B. vulgaris, (b) S. brachycladum

\subsubsection{Water Resistance}

An extensive increase of water uptake at the early stage of $1600 \mathrm{~h}$ water soaking was observed for composites from both bamboo species, especially for 50\% particles loading (Figures 9 and 10). This was followed by a gradual raise thereafter, until the completion of water absorption measurement. Although increased rapidly, composites with 50\% particles loading reached the equilibrium level faster than $25 \%$ loading. In relation to this observation, the water absorption of bamboo particles-PVC composites can be typically divided into two diffusion steps: the first one occurred over a rapid diffusion rate, while the second one was at a slower rate close to zero (Petchwattana, Covavisaruch, \& Pitidhammabhorn, 2013).

A significant different of composites' water uptake property was recorded between different particles size. Composites with fine bamboo particles $(75-\mu \mathrm{m})$ have less water uptake percentage compared to composites with large bamboo particles (1-mm). The low water uptake percentage of composites with fine particles was probably due to the compact mixture between fine particles and matrix which influenced the less water absorption. Compared with large filler in composition, the use of fine particles in the composition reduces the voids formation (Yu, Huang, \& Yu, 2014). Consequently, fillers with a smaller particles size have a higher adhesion interaction with polymer than those with large size (Zazyczny \& Matuana, 2005). This phenomenon reduces the tendency of composites to absorb water.

On the other hand, composites with $25 \%$ bamboo particles show less water uptake compared to composites with $50 \%$ particles. In a comparison to pure PVC (Figure 9 (a) and 10 (a)), water uptake of bamboo particles-filled PVC composites was extremely higher due to the high water uptake capability of bamboo particles as natural filler. The presence of hydrophilic-OH groups in the fibres/particles has influenced the high moisture uptake capacity of any types of natural filled-polymer composites (Samal et al., 2009).

Composites with high lubricants concentration $\left(\mathrm{C}_{2}\right)$ showed lower water uptake percentage compared to low lubricants concentration level $\left(\mathrm{C}_{1}\right)$. The presence of internal and external lubricants at high content level has reduced the water uptake ability. It is recorded in Figure 9 (b) and 10 (b) that composite from $\mathrm{C}_{2}$ group using $75-\mu \mathrm{m}$ particles sieve size with $25 \%$ particles mixing ratio exhibited the lowest water uptake percentage throughout the entire soaking period.

As a comparison, the water uptake property of Malaysian bamboo particles-PVC composites in this study is considered favourable when referring into the other study by Kassim (1999) (increases of 750\% water absorption of composites from 10 to 50\% bamboo fillers loading) and Kushawa and Kumar (2009) (water uptake values of bamboo fibre-epoxy composites (at $64 \%$ bamboo loading) of up to $40 \%$ ). 


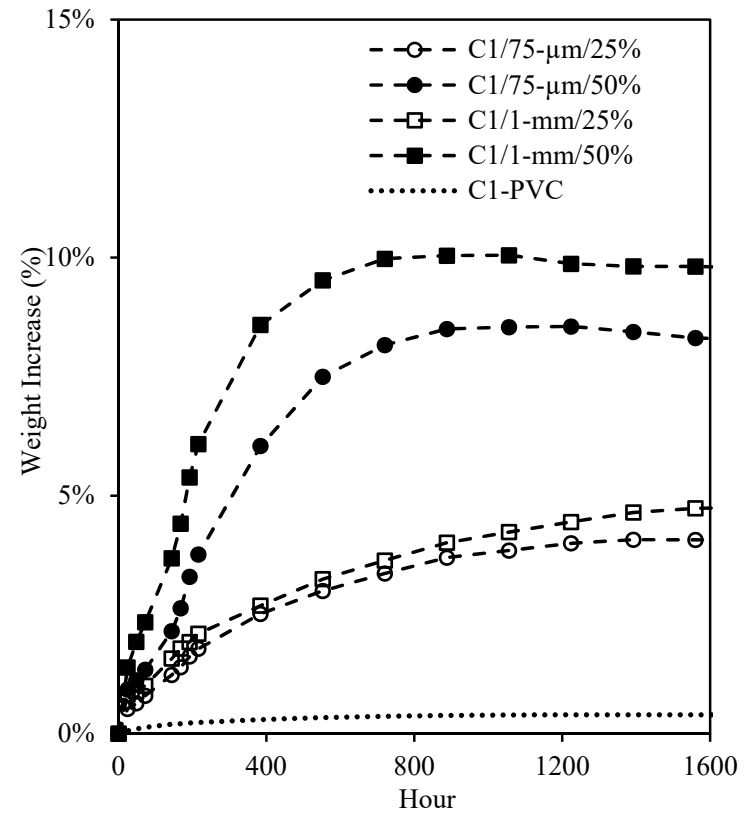

(a)

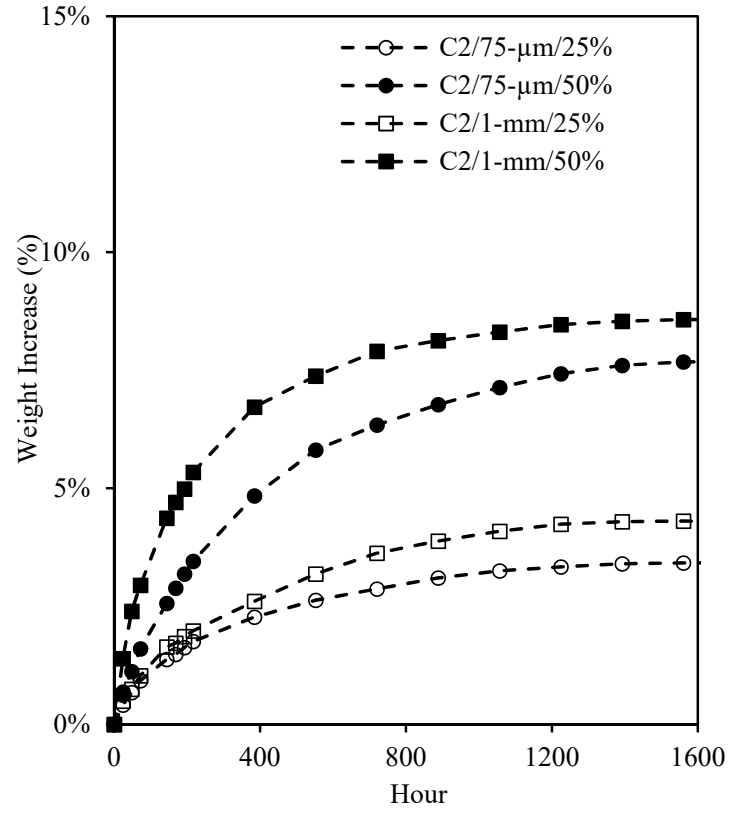

(b)

Figure 9. Water uptake of $B$. vulgaris particles-PVC composites for both $\mathrm{C}_{1}$ and $\mathrm{C}_{2}$ using different particles size, particles mixing ratio, and processing lubricants content level: (a) $\mathrm{C}_{1}$, (b) $\mathrm{C}_{2}$

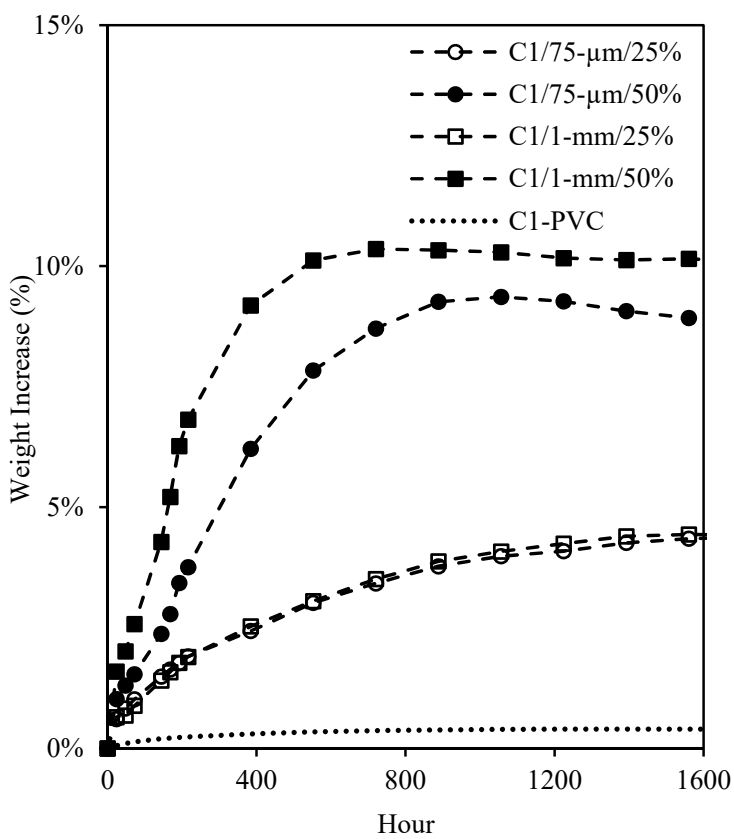

(a)

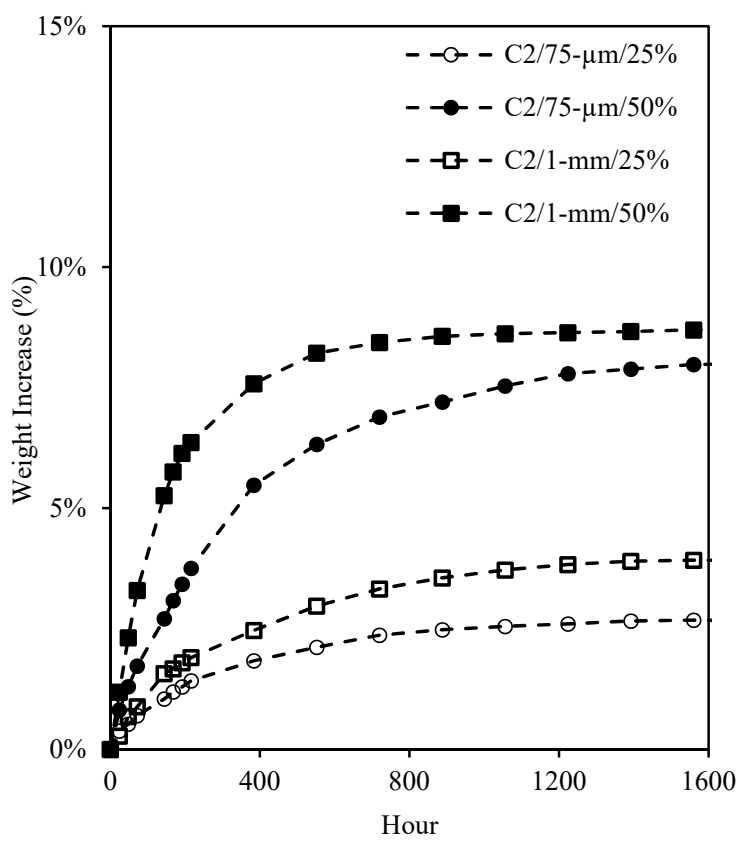

(b)

Figure 10. Water uptake of S. brachycladum particles-PVC composites for both $\mathrm{C}_{1}$ and $\mathrm{C}_{2}$ using different particles size, particles mixing ratio, and processing lubricants content level: (a) $\mathrm{C}_{1}$, (b) $\mathrm{C}_{2}$

\section{Conclusion}

DIA revealed a wide distribution of Malaysian bamboo particles (B. vulgaris and S. brachycladum) length ranged from 0 to $1500 \mu \mathrm{m}$. Insufficient amount of actual particles length distribution from each sieve size $(75-\mu \mathrm{m}$ and 1-mm) has been also recorded. Aspect ratio has been increased with particles length, although particles from small 
sieve size group exhibited a little more elongation than $1 \mathrm{~mm}$. Due to these features, particles size had only a minor impact on the composites performance. Simultaneously, bamboo particles loading has tremendously increased the bending modulus and tensile modulus of PVC composites, however in contrast, decreased the resistance towards maximum bending load, maximum tensile load, impact and water uptake. The consumption of high processing lubricant content level in composites provided remarkably support with regard to impact load, and promoted better resistance towards water absorption. No significant different of composites performance has been recorded between different bamboo species. It is concluded that Malaysian bamboo particles are possible to be mixed with $\mathrm{PVC}$ to produce composites, with particles loading plays the most important role in the composite's properties.

\section{Acknowledgements}

This research has been supported by the German Research Foundation (DFG), grant GRK 1703/1 for the Research Group 'Resource Efficiency in Corporate Networks - Planning Methods to Utilize Renewable Resources'. The authors would like to thank to the Faculty of Applied Sciences, Universiti Teknologi MARA, Shah Alam, Malaysia, for providing machineries (cross-cut and hammer milling machines) during the initial preparation of bamboo particles in Malaysia.

\section{References}

Atuanya, C. U., Government, M. R., Nwobi-Okoye, C. C., \& Onukwuli, O. D. (2014). Predicting the mechanical properties of date palm wood fibre-recycled low density polyethylene composite using artificial neural network. International Journal of Mechanical and Materials Engineering, 7(1), 20.

Bouza, R., Lasagabaster, A., Abad, M. J., \& Barral L. (2008). Effects of vinyltrimethoxysilane on thermal properties and dynamic mechanical properties of polypropylene-wood flour composites. Journal of Applied Polymer Sciences, 109, 1197 - 1204.

Carus, M., \& Eder, A. (2014). Biocomposites: 352,000 t of wood and natural fibre composites produced in the european union in 2012. Wood-Plastic Composites (WPC) and Natural Fibre Composites (NFC): European and Global Markets 2012 and Future Trends. Nova Institute GmbH.

Chen, X., Guo, Q., \& Mi, Y. (1998). Bamboo fiber-reinforced polypropylene composites: a study of the mechanical properties. Journal of Applied Polymer Science, 69, 1891 - 1899.

Chen, Q., Mao, X., Xue, H., Deng, Y., \& Lin, J. (2013). Preparation and characterization of bamboo fiber-graft-lauryl methacrylate and its composites with polypropylene. Journal of Applied Polymer Science, 130(4), 2377 - 2382. DOI: 10.1002/APP.39347.

Clemons, C. (2008). Raw materials for wood-polymer composites. In Wood-Polymer Composites, edited by Niska, K. O. \& Sain, M. Woodhead Publishing, Ltd. Cambridge, UK.

Deutsches Institut für Normung (DIN). (2003). Kunstoffe - bestimmung der biegeeigenschaften - Teil 1. Nicht instrumentierte Schlagzähigkeitsprüfung. DIN EN ISO 178.

Deutsches Institut für Normung (DIN). (1993). Kunstoffe - bestimmung der zugeigenschaften - Teil 1. Algemeine Grundsätze. DIN EN ISO 527 - 1.

Deutsches Institut für Normung (DIN). (2006). Kunstoffe - bestimmung der charpy-schlageigenschaften - Teil 1. Nicht instrumentierte Schlagzähigkeitsprüfung. DIN EN ISO $179-1$.

Gardner, D. J., Han, Y., \& Wang, L. (2015). Wood-plastic composite technology. Current Forestry Reports, 1, 139 -150 .

Ge, X. C., Li, X. H., \& Meng, Y. Z. (2004). Tensile properties, morphology, and thermal behavior of pvc composites containing pine flour and bamboo flour. Journal of Applied Polymer Science, 93, $1804-1811$.

Gozdecki, C., Zajchowski, S., Kociszewski, M., Wilczyñski, A., \& Mirowski, J. (2011). Effect of wood particle size on mechanical properties of industrial wood particle-polyethylene composites. Polimery, 56(5), 375 380.

Grüneberg, T. (2010). Improvement of selected properties of wood-polymer composites (wpc) - silane modification of wood particles. Doctoral dissertation, Georg-August-Universität Göttingen, Germany.

Gupta, A., \& Kumar, A. (2008). Potential of bamboo is sustainable development. Asia Pacific Business Review, IV(3), $100-107$.

Hua, L. Z., \& Kobayashi, M. (2004). Plantation future of bamboo in china. Journal of Forestry Research, 15(3), $233-242$. 
International Organization for Standardization ISO 62. (2008). Plastics-determination of water absorption.

International Organization for Standardization ISO/DIS 14488. (2007). Sample preparation - sampling and sample splitting of particulate materials for the characterization of particulate properties.

Kassim, J. (1999). Properties of particleboard and particle-filled thermoplastic composite from bamboo (GigantochloaScortechinii). Doctoral dissertation, Universiti Putra Malaysia, Malaysia.

Kassim, J., Rahman, W. M. N. W. A., \& Ramlan, M. N. B. (2007). Mechanical and physical properties of araucaria fibre-PP composite. Journal Gading, 11, 1 - 10.

Ke, C. H., \& Jyh, H. W. (2010). Mechanical and interfacial properties of plastic composite panels made from esterified bamboo particles. Journal of Wood Science, 56, 216 - 221.

Kim, J. K., \& Pal, K. (2010). Recent advances in the processing of wood-plastic composites. Springer-Verlag Berlin Heidelberg, Germany.

Kim, J. Y., Peck, J. H., Hwang, S. H., Hong, J., Hong, S. C., Huh, W., \& Lee, S. W. (2008). Preparation and mechanical properties of poly(vinyl chloride)/bamboo flour composites with a novel block copolymer as a coupling agent. Journal of Applied Polymer Science, 108, 2654 - 2659.

Kim, J. H., Shim, B. S., Kim, H. S., Lee, Y. J., Min, S. K., Jang, D., Abas, Z., \& Kim, J. (2015). Review of nanocellulose for sustainable future materials. International Journal of Precision Engineering and Manufacturing-Green Technology, 2(2), 197 - 213.

Kushwaha, P. K., \& Kumar, R. (2010). Studies on water absorption of bamboo-epoxy composites: effect of silane treatment of mercerized bamboo. Journal of Applied Polymer Science, 115(3), 1846 - 1852.

Lee, S. Y., Chun, S. J., Doh, G. H., Kang, I. A., Lee, S., \& Paik, K. H. (2009). Influence of chemical modification and filler loading on fundamental properties of bamboo fibers reinforced polypropylene composites. Journal of Composite Materials, 43(5), 1639 - 1657.

Lutz Jr., J. T., \& Dunkelberger, D. L. (1992). Impact modifiers for pvc: the history and practice. Wiley, New York.

Migneault, S., Koubaa, A., Erchiqui, F., Chaala, A., Englund, K., Krause, C., \& Wolcott, M. (2008). Effects of fibre length on processing and properties of extruded wood-fibre/HDPE composites. Journal of Applied Polymer Science, 110, 1085 - 1092.

Mohanty, S. \& Nayak S. K. (2010). Short bamboo fiber-reinforced hdpe composites: influence of fiber content and modification on strength of the composite. Journal of Reinforced Plastics and Composites, 29(14), 2199 2210.

Müller, M. (2012). Influence of wood modification on the properties of polyvinyl chloride based wood polymer composites (wpc). Doctoral dissertation, Cuvillier Verlag, Göttingen, Germany.

Petchwattana, N., Covavisaruch, S., \& Pitidhammabhorn, D. (2013). Influence of water absorption on the properties of foamed poly(vinyl chloride)/rice hull composites. Journal of Polymer Research, 20, $172-178$. DOI: $10.1007 / \mathrm{s} 10965-013-0172-\mathrm{y}$.

Robinson, S., Ferrigno, T. H., \& Grossman, R. F. (2008). In R. F. Grossman (Ed.), Handbook of vinyl formulating. John Wiley and Sons Inc., USA.

Samal, S. K., Mohanty, S. \& Nayak, S. K. (2009). Polypropylene-bamboo/glass fiber hybrid composites: fabrication and analysis of mechanical, morphological, thermal, and dynamic mechanical behavior. Journal of Reinforced Plastic and Composites, 28(22), 2729 - 2747.

Satov, D. V. (2008). Additives for wood-polymer composites. In Wood-Polymer Composites, edited by Niska, K. O. \& Sain, M. Woodhead Publishing, Ltd. Cambridge, UK.

Sheng, K. C., Qian, S. P., \& Wang, H. (2014). Influence of potassium permanganate pretreatment on mechanical properties and thermal behavior of moso bamboo particles reinforced pvc composites. Polymer Composites, $35,1460-1465$.

Stark, N. M., \& Gardner, D. J. (2008). Outdoor durability of wood-polymer composites. In Wood-Polymer Composites, edited by Niska, K. O. \& Sain, M. Woodhead Publishing, Ltd. Cambridge, UK.

Stark, N. M., \& Rowlands, R. E. (2003). Effects of wood fiber characteristics on mechanical properties of wood/polypropylene composites. Journal of Wood and Fiber Science, 35(2), $167-174$.

Tewari, D. N. (1993). Monograph on bamboo. International Book Distributors, India. 
Thacker, G. A. (2008). Formulating rigid pvc for extrusion. In Grossman, R. F. (Ed.), Handbook of vinyl formulating. John Wiley and Sons Inc., USA.

Wahab, R., Samsi, H. W., Ariffin, W. T. W., \& Mustafa, M. T. (1997). Industri pembuatan pepapan laminasi buluh. FRIM Technical Information Handbook No. 11, Forest Research Institute Malaysia (FRIM), Malaysia.

Wang, H., Sheng, K. C., Lan, T., Adl, M., Qian, X. Q., \& Zhu, S. M. (2010). Role of surface treatment on water absorption of poly (vinyl chloride) composites reinforced by phyllostachys pubescens particles. Composites Science and Technology, 70, $847-853$.

Wong, K. M. (1995). The bamboo of peninsular Malaysia. Forest Research Institute Malaysia (FRIM), Malaysia.

Yu, Y. L., Huang, X. A., \& Yu, W. J. (2014). High performance of bamboo-based fiber composites from long bamboo fiber bundles and phenolic resins. Journal of Applied Polymer Science, 131(12), 1 - 8. http://dx.doi.org/10-1002/APP.40371.

Zazyczny, J. M., \& Matuana, L. M. (2005).Fillers and reinforcing agents. In C. E. Wilkes, J. W. Summers, \& C. A. Daniels (Eds.), PVC Handbook (pp. 235 - 275).

\section{Copyrights}

Copyright for this article is retained by the author(s), with first publication rights granted to the journal.

This is an open-access article distributed under the terms and conditions of the Creative Commons Attribution license (http://creativecommons.org/licenses/by/4.0/). 